\title{
Proposition 13 threatens US basic research
}

\section{David Dickson describes fears expressed at a recent meeting of the AAAS on federal research and development}

PRESIDENT Carter's much-welcomed boost for basic research in his budget proposals for 1979 is beginning to look like a short-lived affair, faced with demands from tax-payers-in the wake of California's "Proposition 13"--and from economists for a reduction in spending. Already the president has had to appeal to Congressional appropriations committees to respect the integrity of his carcfully-structured research and development package, following attempts to subject it to piecemeal cuts.

In the longer tcrm, the administration is facing an uphill battlc defending the logic of its position that R \& D is an important national priority in need of greater support than it has been receiving in recent years.

President Carter's appeal was made two weeks ago in a letter to the chairmen of the relevant committees and subcommittees. In particular, it was timed to coincide with a meeting at which the Senate appropriations committee was to have considered a proposal to cut the appropriation to the National Science Foundation by $\$ 44$ million (a cut which was approved by the House last week).

As it turned out, the Senate committee ducked the issue by sticking closely to procedural rules and stating that it would not consider the NSF appropriations until the relevant authorisation bill had been passed by the Senate - which is not expected for a few weeks.

However even if Congress restores the cuts as the president has requested, the problems for basic research are far from over. Mr W. Bowman Cutter, for example, executive associate director of the Office of Management and Budget, had few words of comfort when he spoke last week to a two-day meeting on federal research and development policy organised by the American Association for the Advancement of Science.

Stressing growing concern about the effects of inflation, as well as the president's determination to cut the budget deficit, Mr Cutter said that the 1980 budget was likely to be "the tightest budget in a decade", with cuts across the board in order to make a convincing case for general constraint.

Many at the mecting drew caution from these remarks, as well as from the recent Congressional actions on the 1979 budget requests. "This may be a signal that there is to be a levelling off after one year of attempted build-up," warned Mr William Carey, an $\mathrm{cx}$-White House budget official and now executive secretary of the AAAS.

There was little pessimism in the keynote address given by Dr Frank Press, director of the Office of Science and Technology Policy. Emphasising the need for a better definition of, and greater consensus on, long-term goals for the federal role in $\mathrm{R} \& \mathrm{D}$, Dr Press said that "therc is clearly a good case now for more rational management of the nation's planning and support of its science and technology in the face of their critical relationship to our future".

Dr Press said that during the past year, the administration has initiated new thrusts in areas such as human nutrition, competitive agricultural research grants, climate research and earthquake hazard reduction. "In the coming year, I think we can look forward to many more accomplishments --even in the face of strong challenges and stringent priority-setting." he said.

A central theme of the AAAS meeting-and one that has occupied much of Dr Press' time at OSTP -- was the relationship between the declining productivity of US industry and recent decreases in federal support for R\&D. In particular, concern has been expressed at industry's apparent shift away from long-range research goals offering the possibility of major technological innovations, towards shorterterm goals concerned largely with product development.

However, while admitting that this process had taken place, few of the industrial representatives at the meeting saw this as a major problem. More relevant obstacles to successful innovation. in their eyes, were the inhospitability of the economic climate, and the uncertainty surrounding future government regulations.

A major implication of this shift in industry to short-term research has been to increase the relative responsibility of the university sector for the conduct of basic rescarch. "Universities still provide the best environment by far for the long-term focus and pluralistic approach so essential to basic research," said Mr Russell Peterson, recently-appointed director of the Office of Technology Assessment.

Yet as a number of speakers pointed out, the universities' current ability to meet this responsibility is far from happy. Much of the 5 per cent increase proposed by the president for basic research over the increase in cost of living would, for example, be needed to replace out-dated equipment.

There was a measure of agreement that more should be done to encourage co-operation between universities and industry in carrying out research projects. Also that policies on patent rights, and on legitimate rates for "overheads" charged on federal research contracts - two current thorns in the side of the administration should be sorted out in a mutuallyacceptable way.

Dr John Sawhill, a previous associate director of OMB and now president of New York University, argued for a system of decentralised grant-making for interdisciplinary research projects of social relevance which would operate in parallel with the existing system, but for which applications would be subject to an internal peerreview within educational institutions.

Congress already sceptical of the peer review process, and is reluctant to dispense funds which cannot readily be accounted for. It does not therefore appear to be in the mood for any such major institutional innovations (a large proportion of the funds which the House has cut from the NSF's budget had been intended for applied research and social science projects).

But without such new initiatives, basic research is left in a relatively weak position. As long as the relationship between basic research and technological development is left an article of faith rather than a clearly-delineated mechanism, it remains vulnerable to the marauding attacks of those seeking quick political victories.

In the present climate, neither industry nor the president's economic advisers are putting much emphasis on the need for federal stimulation of basic research; as $\mathrm{Mr}$ Carey pointed out, there is no mention of R\&D in the latest annual report of the Council of Economic Advisers.

Furthermore, Congress' piecemeal attempts to limit public expenditure are not merely threatening to hold back isolated pieces of research, but are also undermining the logic of the strategy by which Dr Press put the budget package together.

$\mathrm{OMB}$ is about to send out to Government agencies and departments its guidelines for budget requests for the fiscal year 1980 . Whether, by the time these have been whittled down into the President's budget statement next January, these will provide a strong case for any further increase in the support of basic research over and above the proposals in this year's budget message remains to be seen. 